\title{
34
}

\section{Reforming Constitutional Reform}

\author{
Scott Stephenson
}

\section{Introduction}

This chapter proposes that Australia's constitutional reform process could be reformed through the use of citizen-led conventions with broad remits to consider a range of constitutional issues. It sets out the case for this reform by answering three questions: why should we think about reforming the constitutional reform process, what is wrong with the current process, and how can it be improved?

\section{Why Should We Think about Reforming the Constitutional Reform Process?}

There are a number of important issues in contemporary Australian life that have a constitutional dimension and are the subject of discussions that include options for change. Federalism, the protection of fundamental human rights and the recognition of Indigenous persons are three prominent examples where the options for change are an integral part of the conversation. There are also other issues where analysis often takes a normative bent such as the process by which major international treaties are drafted, ratified and implemented (e.g. the Trans-Pacific Partnership

1 Senior Lecturer, Melbourne Law School, University of Melbourne. 
Agreement) and the mechanisms for holding to account private companies that perform public functions (e.g. the operation of overseas immigration detention facilities). Due to their constitutional dimensions, consideration of the full range of options for change requires putting the possibility of constitutional amendment on the table.

Constitutional amendment will not always be the preferred option for change, but any discussion where the possibility is foreclosed will be partial and, consequently, substandard. An illustration is the National Human Rights Consultation Committee, which was established in 2008 to investigate how Australia could better protect and promote human rights, but was precluded from recommending a constitutionally entrenched bill of rights. ${ }^{2}$ Taking constitutional amendment off the table not only eliminated one option from consideration, but also confined the range of other options that could be proposed. The committee's discussion of the different types of statutory bills of rights was limited by the fact that certain models might be precluded by the Constitution's separation of powers doctrine. ${ }^{3}$ The protection of fundamental human rights is an issue that has seen a large degree of innovation in recent decades, ${ }^{4}$ yet the committee was unable to consider the full range of options and determine which one might be the most appropriate for Australia once the possibility of constitutional amendment was taken off the table. The committee's proposed set of reforms reflected these constraints. The reforms were so modest in scope that the committee and academic commentators found it difficult to identify what, as a practical matter, they would change. ${ }^{5}$

Even when constitutional amendment is put on the table, the difficulty of securing an amendment tends to confine the conversation by focusing on the most modest options for change. More ambitious proposals are dismissed not on their merits, but instead due to the common belief that anything more than the most modest change will be defeated at a referendum. We saw this dynamic emerge in the debate on constitutional recognition of Indigenous persons. Efforts were made to direct the

\footnotetext{
2 National Human Rights Consultation, Report (September 2009) Appendix A.

3 Ibid. 373-76.

4 See, for example, Stephen Gardbaum, The New Commonwealth Model of Constitutionalism: Theory and Practice (Cambridge University Press, 2013); Scott Stephenson, From Dialogue to Disagreement in Comparative Rights Constitutionalism (Federation Press, 2016).

5 Scott Stephenson, 'Constitutional Reengineering: Dialogue's Migration from Canada to Australia' (2013) 11 International Journal of Constitutional Law 870, 889-93.
} 
conversation - contrary to the wishes of many Indigenous persons ${ }^{6}-$ towards the most modest proposals (e.g. to include a declaration in the Preamble to the Constitution) and away from more ambitious proposals (e.g. to include a legally enforceable non-discrimination provision) on the ground that the latter would not survive the Constitution's difficult amendment procedure. ${ }^{7}$

Therefore, it is arguable that we should reform the constitutional reform process in order (1) to allow the possibility of constitutional amendment to be put on the table when discussing issues that the Constitution affects and (2) to allow the full range of options for change, including ambitious proposals, to be discussed on their merits when constitutional amendment is on the table.

\section{What Is Wrong With the Constitutional Reform Process?}

It is tempting to attribute the abovementioned trends solely to the difficulty of Australia's constitutional amendment procedure. After all, it is understandable that one would want to keep constitutional amendment off the table or, if it is put on the table, to focus on modest proposals if the likelihood of success is low. And it is beyond doubt that Australia's constitutional amendment procedure is difficult. Prime Minister Robert Menzies' colourful comment captures this widely shared view: 'The truth of the matter is that to get an affirmative vote from the Australian people on a referendum proposal is one of the labours of Hercules'. ${ }^{8}$ Comparative constitutional analysis confirms his statement, with Australia having one of the world's most difficult constitutions to amend. ${ }^{9}$ However, I argue that the difficulty thesis is too simple. It supplies only part of the picture.

6 See, for example, Megan Davis and Marcia Langton (ed), It's Our Country: Indigenous Arguments for Meaningful Constitutional Recognition and Reform (Melbourne University Press, 2016).

7 Paul Kelly, 'To Succeed, Indigenous Recognition Must Be Handled Deftly', The Australian, 10 September 2014, www.theaustralian.com.au/opinion/columnists/paul-kelly/to-succeed-indigenousrecognition-referendum-must-be-handled-deftly/news-story/cd0fbee39cde82ac00297ecc9fa4bd6d.

8 Quoted in Leslie Finlay Crisp, Australian National Government (Longman Cheshire, $5^{\text {th }}$ edn, 1983) 40 .

9 George Williams and David Hume, People Power: The History and Future of the Referendum in Australia (UNSW Press, 2010) 11. 
The other part of the picture is the ease of the constitutional amendment procedure. When a constitutional amendment procedure becomes so difficult that it is unworkable in practice, institutional actors will be inclined to start again and install a new procedure - perhaps even in violation of the existing procedure - as has been the case in countries such as Canada and the US. ${ }^{10}$ Australia has not reached this point. The country's small number of successful constitutional amendments eight since 1901 - appears to have convinced most institutional actors and scholars that the reform process is fundamentally sound and that all that is required is better execution. This explains why many proposals for reform of the constitutional reform process are modest suggestions that focus on issues of implementation such as greater education of the public and more bipartisanship. ${ }^{11}$ These are valuable suggestions that are worthy of implementation, but they are arguably insufficient to remedy the problem that emerges once we put together both parts of the picture - the ease and difficulty theses.

Australia's history of constitutional amendment demonstrates that it is possible to achieve minor or technical change (the ease thesis), but also suggests that major change is largely beyond the reach of the current process (the difficulty thesis). It has been possible to make a small number of amendments to the Constitution since it came into force in 1901, but most have been minor or technical in character. One possible exception is the 1946 amendment granting Commonwealth Parliament the power to provide a range of social services, an essential component of the welfare state. However, even it was understood as a technical fix to secure a function that parliament was already performing rather than to give parliament power to undertake a new set of functions. ${ }^{12}$ Another possible exception is the 1967 amendments concerning the treatment of Aboriginal people. However, it made only minor modifications in

10 The US Constitution, including its new amendment procedure, was established in violation of the amendment procedure contained in the Articles of Confederation (see Bruce Ackerman, We the People: Foundations (Belknap Press, 1991) 41-42) and in 1980 in Canada the Prime Minister, Pierre Trudeau, threatened to violate the constitutional convention concerning the procedure for amending the Constitution to install a new amendment procedure (see Scott Stephenson, 'When Constitutional Conventions Fail' (2015) 38 Dublin University Law Journal 447, 459-63).

11 See, for example, Williams and Hume, People Power, above n 9, 239; Graeme Orr, 'Voluntary Voting for Referendums in Australia: Old Wine, New Bottle', Ch 33.

12 The amendment was spurred by a High Court decision that cast doubts on the head of power on which parliament had relied: Attorney-General (Vic) ex rel Dale v Commonwealth (1945) 71 CLR 237. 
substantive terms, ${ }^{13}$ altering which level of government could legislate with respect to Aboriginal people and allowing Aboriginal people to be counted in the census. It did not, for instance, give them the right to vote (already by then granted through ordinary legislation), recognise them as the first inhabitants of Australia or prohibit racial discrimination.

Major amendment is a different form of constitutional change than minor or technical amendment because the former requires public ownership of the amendment process - it is not merely fixing an error or oversight, but changing the nature of the bargain that is struck between the government and the people. If the people do not understand the new bargain to be one that they have authored, there is ample reason for them to use the power given to them by the referendum requirement in $s 128$ to reject it. Therefore, the referendum requirement is not equivalent to, or a substitute for, public ownership of the amendment process. It ensures that the people get a chance to ratify a proposal, but it does not ensure that they have any say over the identity or content of the proposal.

When examining the constitutional reform process through the lens of public ownership, Australia has an unimpressive record albeit with some exceptions. The Australian Constitutional Convention convened from 1973 to 1985 exemplifies the historical tendency to adopt an exclusive rather than inclusive process to the authorship of amendment proposals. It was comprised solely of representatives from government and, perhaps unsurprisingly, split along the same party lines that exist in the legislative chambers. ${ }^{14}$ The Constitutional Commission established in 1985 was scarcely any better, comprised of a group of unelected and unrepresentative political and legal elites such as former Prime Ministers and GovernorsGeneral. However, the commission did take some steps to include the people in the process, conducting public hearings across the country and inviting written submissions. ${ }^{15}$ The people nevertheless had no direct role in contributing to the identity or content of the commission's proposals - they were outsiders rather than insiders. The Constitutional Convention commissioned in 1998 to consider whether Australia should become a republic was a significant improvement over prior efforts: half of the delegates were elected by a voluntary postal vote while the other

13 This is not to deny the symbolic importance of the events in 1967 , especially as the proposal received the support of almost 91 per cent of the electorate.

14 Williams and Hume, People Power, above n 9, 28.

15 Ibid. 30. 
half were appointed by government in consultation with other groups. ${ }^{16}$ This format had its shortcomings - in particular, the Convention focused on a single issue and thus most of the elected volunteers were prominent public figures with strong views on the issue of republicanism to the exclusion of ordinary members of the public. But it nevertheless helped generate an unprecedented level of popular interest and involvement in the constitutional amendment process. For instance, large numbers of people watched the Convention's proceedings in person and on television.

\section{How Can the Constitutional Reform Process Be Improved?}

The Irish Constitutional Convention held from 2012 to 2014 demonstrates the scope for innovation with respect to the constitutional reform process. My argument is not that Australia should slavishly follow the Irish model, but that it should prompt Australia to reconsider how, and the extent to which, the public can be included in the process of determining the identity and content of proposals for major constitutional amendment. The Irish Constitutional Convention was established to consider eight areas of reform, including the voting age, the electoral system, same-sex marriage and the participation of women in politics, as well as any other relevant constitutional amendments that it recommended. It had 100 members: a chairperson, 33 legislators and 66 citizens of Ireland randomly selected in a manner designed to reflect the age, geographical and gender balance of the electorate. The government did not commit to proceeding with the Convention's recommendations, but did commit to respond formally to each recommendation and to debate it in the legislature.

The Convention met over 10 weekends for a day and a half each time. ${ }^{17}$ Sessions included presentations by experts of papers which had been circulated in advance, debates between groups advocating on either side of an issue, and roundtable discussions before votes were taken. The Convention considered two additional subjects (reform of the lower house and the inclusion of economic, social and cultural rights) and issued nine reports, containing a range of recommendations. The government has responded to six of the reports thus far, and put two

\footnotetext{
16 Ibid. 183.

17 Tom Arnold, 'Inside the Convention on the Constitution', The Irish Times, 1 April 2014, www.irishtimes.com/news/politics/inside-the-convention-on-the-constitution-1.1744924.
} 
of its recommendations to the people at a referendum held on 22 March 2015. One recommendation, the legalisation of same-sex marriage, was accepted and the other, the reduction in the age of eligibility for the president, was rejected.

The Irish Constitutional Convention contains two principal insights that are relevant to Australia. First, it demonstrates that it is possible to bring the people into the constitutional reform process in a direct and significant way. Ordinary members of the public were given a seat at the table rather than, for example, an invitation to make submissions, and constituted a majority of the Convention, giving their views considerable weight. Second, it demonstrates the potential value of establishing a forum that has a broad remit to consider a range of constitutional issues. Constitutions are interconnected instruments that make it difficult and even problematic to consider issues in isolation. A convention with a wide agenda or a power to investigate (or recommend the investigation of) additional issues can take a holistic approach to reform. For example, the Irish Constitutional Convention used its final report to recommend a second convention to examine, among other things, reform of the legislature's upper house to complement its recommendations for reform of the lower house. Further, this format helps reduce problems associated with participants being strongly committed to a single issue, by requiring compromise and engagement across multiple issues.

Most reflections on the Irish Constitutional Convention have been positive, with commentators suggesting that it demonstrates that ordinary citizens can engage with complex constitutional issues in an enthusiastic and sophisticated manner and that this format can produce real and radical change. ${ }^{18}$ While it has not escaped criticism, most of the problems that have been identified relate to the way in which it was set up rather than the concept of citizen-led constitutional reform. ${ }^{19}$ For example, some criticisms include that the government was under no obligation to put the Convention's recommendations to the people, that there was a lack of

18 Ivana Bacik, 'Can a Constitutional Convention Offer Real and Radical Change?', LSE Blog, 15 December 2014, blogs.lse.ac.uk/constitutionuk/2014/12/15/can-a-constitutional-convention-offerreal-and-radical-change/. See also Matthew Wall, 'Change We Can Believe In? Ireland's Constitutional Convention Has Delivered', TheJournal.ie, 23 July 2013, www.thejournal.ie/readme/column-changewe-canbelieve-in-ireland\%E2\%80\%99s-constitutional-convention-has-delivered-1003278-Jul2013/; David Farrell, 'The Irish Constitutional Convention Offers a Potential Route-Map for Renewing UK Democracy', Democratic Audit UK, 10 October 2014, www.democraticaudit.com/?p=8625.

19 But cf Eoin Carolan, 'Ireland's Constitutional Convention: Behind the Hype about Citizen-Led Constitutional Change' (2015) 13 International Journal of Constitutional Law 733. 
balance in the 'expert' material put before participants and the insufficient resources allocated to the Convention. ${ }^{20}$ These issues point to a final lesson for Australia from the Irish experience: the details matter.

It is not the case that any participatory forum - irrespective of its design will help generate public ownership of the constitutional reform process. Instead, it must be a forum that is established and executed in a way that renders it democratic (i.e. the forum is comprised in a way that represents the people) and deliberative (i.e. the forum is structured in a way that the people's views are heard and influence the outcome of proceedings). A discussion of the full range of considerations that should be taken into account to create such a forum is beyond the scope of this chapter, ${ }^{21}$ but the Irish experience does provide a number of helpful points in this regard. For example, the selection process was structured in a way to ensure that a representative group of the population was chosen. ${ }^{22}$ Furthermore, the proceedings were structured in a way to minimise the risk that the political participants would dominate discussion and to ensure that exchanges were open, fair, equal, efficient and collegial. ${ }^{23}$

\section{Conclusion}

A citizen-led convention with a broad remit to consider a range of constitutional issues would be a significant but far from radical development. As the Irish experience illustrates, large swathes of major constitutional reform will not necessarily eventuate. Indeed, the problem that I have identified with the current process is not a lack of major constitutional amendments. The Australian people are entitled to decide that the current arrangements serve them the best. Instead, the problem is a lack of opportunities to deliberate the full range of constitutional options and, in particular, a lack of opportunities for the people to deliberate which options are put on the table - that is, a constitutional reform process that they own. The Irish Constitutional Convention provides a contemporary example of the scope for innovation in establishing such a process.

20 Ibid. 745-48.

21 For a more detailed discussion of the issues, see Ron Levy, 'Breaking the Constitutional Deadlock: Lessons from Deliberative Experiments in Constitutional Change' (2010) 34 Melbourne University Law Review 805; Paul Kildea, 'A Little More Conversation? Assessing the Capacity of Citizens to Deliberate About Constitutional Reform in Australia' (2013) 22 Griffith Law Review 291. 22 The selection process was not, however, without its problems: Carolan, 'Ireland's Constitutional Convention', above n 19, 741-42.

23 Arnold, 'Inside the Convention on the Constitution', above n 17. 
This text is taken from New Directions for Law in Australia: Essays in Contemporary Law Reform, edited by Ron Levy, Molly O’Brien, Simon Rice, Pauline Ridge and Margaret Thornton, published 2017 by ANU Press, The Australian National University, Canberra, Australia. 